\title{
THE EFFECT OF OUTSIDE AIR TEMPERATURE ON TRANSPORTATION TEMPERATURES AND PROCESSING QUALITY OF COW'S MILK
}

\author{
Vratislav Henzl ${ }^{1}$, Daniel Falta ${ }^{1}$, Stanislav Navrátil ${ }^{1}$, Francois Lategan ${ }^{2}$ \\ ${ }^{1}$ Department of Animal Science, Faculty of AgriSciences, Mendel University in Brno, Zemědělská 1, 61300 Brno, \\ Czech Republic \\ ${ }^{2}$ Department of Agriculture, Cape Peninsula University of Technology, Wellington 7654, SAR
}

To cite this article: HENZL VRATISLAV, FALTA DANIEL, NAVRÁTIL STANISLAV, LATEGAN FRANCOIS. 2018. The Effect of Outside Air Temperature on Transportation Temperatures and Processing Quality of Cow's Milk. Acta Universitatis Agriculturae et Silviculturae Mendelianae Brunensis, 66(5): 1135-1140.

To link to this article: https://doi.org/10.11118/actaun201866051135

\begin{abstract}
The objective of this study was to assess the effect of outside air temperature on the transportation temperature and processing quality of cow's milk. The data used in the analyses (208 bulk samples) were collected on four farms over a period of 52 consecutive weeks. The samples were grouped into four outside air temperature-based groups, namely: below $1.0^{\circ} \mathrm{C}$; from 1.1 to $8.0^{\circ} \mathrm{C}$; from 8.1 to $15.0^{\circ} \mathrm{C}$; above $15.1^{\circ} \mathrm{C}$. Mean values of the observed characteristics were as follows: average outside air temperature $7.40^{\circ} \mathrm{C}$, milk temperature on dairy farms $5.19^{\circ} \mathrm{C}$ (at collection) and milk temperature on arrival at the dairy factory $5.60^{\circ} \mathrm{C}$. The average duration of transport was 211 minutes, milk volume in the tanker 12,885 , fat content $4.13 \%$, protein content $3.40 \%$, lactose content $4.89 \%$, casein content $2.97 \%$, titratable acidity $6.31 \mathrm{SH}$, active acidity $6.75(\mathrm{pH})$, rennet coagulation time (RCT) 201 sec., curd class 1.11 (on five-point scale) and 1.49 (on ten-point scale). Increasing outside air temperature was closely correlated $(p<0.01$ ) with an increase in milk temperature at the dairy factory (at delivery). A significant ( $p<0.01$ ) increased difference between the temperatures on the farm (at collection) and at delivery in the dairy factory was also recorded. The titratable acidity decreased and so did the curd class on the ten-point scale. Milk temperature on the farm (at point of entering transportation tank) also increased significantly $(\mathrm{p}<0.01)$ with outside air temperature. Other differences were not significant $(p>0.05)$. Findings of this study suggest that outside air temperature influences the properties and processing quality of the transported milk, even though the temperature differences of the milk itself ranged within the acceptable limits. It therefore stands to reason that, when the temperature of milk on load is close to the recommended temperature limits it can exceed this limit during transportation to the dairy factory and cause significant damage to the processing quality of the transported milk.
\end{abstract}

Keywords: milk composition, processing quality, outside air temperature, milk transportation

\section{INTRODUCTION}

Milk processing quality is determined by a number of factors including the fat content, protein content (both crude and true), casein content, lactose content, non-fat solids content, somatic cell count and processing quality, such as titratable acidity, active acidity, alcohol stability, fermentation ability of milk, rennet coagulation time (RCT) and the volume of whey separated in the process of rennet coagulation (Hanuš et al., 
2007, 2010; Janů et al., 2007). Also, composition of casein is important for proper coagulation of milk (Bonfatti et al., 2013). Processing quality is already established in fresh raw milk and is determined by the cow's individual characteristics, genotype or breed (Bayram et al., 2009; Matějíček et al., 2008). They can also be affected by parity and stage of lactation (Summer et al., 2003). The feed ration is also an important factor since it can influence protein content and consequently solids non-fat content (Davis and White, 1958). A study by Cimen et al., (2010) suggested seasonal variations of biochemical characteristics of milk. The processing quality of milk is also influenced by the cow's health condition and heat stress (Hanuš et al., 2008; Varlyakov et al., 2012). Other factors like somatic cell count could also be affected by season (Pašić et al., 2016).

The RCT is significantly $(p<0.01)$ associated with the processing quality of milk and influences the process of cheese making, cheese yield and cheese quality (Johnson et al., 2001). RCT is therefore an essential aspect of the cheese making process (Cassandro et al., 2008). It is generally known, that reducing the $\mathrm{pH}$ of milk from 6.7 to 5.8 leads to shorter RCT and that lower casein content also reduces RCT (Daviau et al., 2000). Jõudu et al. (2008) reported that an increase in milk protein, casein, casein fractions, and casein number resulted in reduced RCT of milk. Nájera et al. (2003) found that increasing temperature reduced RCT while increasing active acidity prolonged it.

Milk temperature plays an important role in milk processing (Riddell-Lawrence and Hicks, 1989; Tyrisevä et al., 2004). Usually, in state norms of EU states, there is recommended that milk should be kept within the temperature limits between 4 and $6{ }^{\circ} \mathrm{C}$. Higher temperatures are generally known to have a negative impact on milk quality, but detrimental effects have also been recorded at temperatures below the generally accepted limits (Legraët and Brulé, 1993; Kirin, 2001). Both dairy farms and dairy factories keep milk in cooling tanks equipped with efficient cooling devices to keep the milk temperature within the limits. However, milk processing can be jeopardised during transportation from the dairy farm to the dairy factory. The tankers transporting milk do not usually have an active cooling system, but only insulation. This could have serious consequences, especially in summer, because milk may be transported over long distances and subject to drastic changes in temperature - often outside the recommended limits. Therefore, it is necessary to determine the effect of outside air temperature on milk temperature and consequently on the processing quality of the transported milk.

\section{MATERIALS AND METHODS}

A total number of 208 bulk milk samples were collected on four dairy farms over a period of 52 consecutive weeks (during the season
7/2012-7/2013), representing a mix of the evening and morning milkings. The samples were collected once a week on the same day at all dairy farms. They were analysed at the collection point on the dairy farm and then again immediately after delivery at the dairy factory.

The following milk characteristics and processing qualities were recorded:

- Milk composition - fat (F;\%), crude protein (P;\%), lactose (L; lactose monohydrate;\%) and casein (C;\%) were recorded using Lactoscope FTIR Advanced after its regular calibration according to relevant reference method results.

- Milk volume in the tanker - measured when collected by the tanker on the sampling day.

- Rennet coagulation time (RCT) was determined by a turbi-dimetric detector of milk coagulation described by Chládek et al., 2011.

- Active acidity (pH) - measured by a pH-meter WTW 197i.

- Titratable acidity (SH) - measured in a 100 ml milk sample using an alkaline solution (0.25mol.1-1NaOH) up to a light pink colour of the sample.

- Air temperature - the average outside air temperature values were provided by the Czech Hydro-meteorological Institute, and were measured at the weather station in Pribyslav (CZ). The samples were allotted into four temperature-based categories: to $1.0^{\circ} \mathrm{C}$; from 1.1 to $8.0^{\circ} \mathrm{C}$; from 8.1 to $15.0^{\circ} \mathrm{C}$; above $15.1^{\circ} \mathrm{C}$. The data were tested using the analysis of variance method with the outside air temperature as independent factor and the sampling week as replication.

- Milk temperature and the duration of transportation - using the system MAK 3002 implemented in tankers. It was automatically measured during the tank filling on the farm and delivery of milk in dairy.

- Curd quality - was evaluated when the curd had set by assessing visual aspects of the curd and whey. The classification scale distinguished either 5 classes (class 1 = the best - firm curd, pure whey; class 5 = the worst - no solid structure) or 10 classes ( $1=$ the best, $10=$ the worst) (methods according Gajdůšek, 1997).

\section{RESULTS AND DISCUSSION}

Milk temperature, milk volume and duration of transportation within the observed outside air temperature range are described in Tab. I. The number of samples in each temperature based class varied between 44 and 56 . The average outside air temperature ranged from $-3.48^{\circ} \mathrm{C}$ to $18.07^{\circ} \mathrm{C}$. The milk temperature at dairy farms ranged between $4.98{ }^{\circ} \mathrm{C}$ and $5.57^{\circ} \mathrm{C}$. Interclass comparisons suggested that the intra-class variation in milk temperature difference between the dairy farm and the factory is most significant $(\mathrm{p}<0.01)$ below $1{ }^{\circ} \mathrm{C}$.

Irrespective of the outside air temperature, the average difference in milk temperature at 
collection on the dairy farm during the observation period never exceeded $0.59^{\circ} \mathrm{C}$. The milk temperature on arrival at the dairy factory ranged between $5.14^{\circ} \mathrm{C}$ and $6.14^{\circ} \mathrm{C}$. This fell well within the recommended limits of $4-6^{\circ} \mathrm{C}$. Interclass comparisons in the variations of milk delivery temperatures at the dairy factory are indicated in Tab. I. The recommended limit was slightly exceeded (by $0.14{ }^{\circ} \mathrm{C}$ ) only in the class with the highest average outside air temperature (above 15. $1^{\circ} \mathrm{C}$ ). In the class with outside air temperatures below $1{ }^{\circ} \mathrm{C}$ the difference was only $0.07^{\circ} \mathrm{C}$, but in the group with outside air temperatures above $15.1^{\circ} \mathrm{C}$ it was $0.57{ }^{\circ} \mathrm{C}$. The value $0.07^{\circ} \mathrm{C}$ was significantly $(\mathrm{p}<0.01)$ lower than all other values. The duration of transport and volume of milk in the tanker did not vary significantly and stayed within the interval between 210 to 212 minutes traveling time, while milk volumes ranged between $12,599 \mathrm{~kg}$ to $13,172 \mathrm{~kg}$.

Milk composition at the observed outside air temperatures is presented in Tab. II. The average fat content was greatest $(4.13 \%)$ in the class with outside air temperatures below $1{ }^{\circ} \mathrm{C}$ (4.27\%) and lowest in the group with temperatures above $15.1{ }^{\circ} \mathrm{C}$ (4.03\%). CHLÁDEK et al. (2011) recorded comparable results-an average fat content $3.81 \%$ (ranging from 3.69 to $3.89 \%$ ) associated with seasonal changes. Polák et al. (2011) recorded fat contents in cow's milk between $3.67 \%$ and $4.41 \%$ with the average $4.11 \%$.

The average protein content (3.40\%) copied the trend of the fat content and decreased with the growing outside air temperature from $3.47 \%$ (the class with outside air temperatures below $1{ }^{\circ} \mathrm{C}$ ) to $3.28 \%$ (the class with outside air temperatures above $15.1{ }^{\circ} \mathrm{C}$ ). This corresponds with findings recorded by Čejna et al. (2006) or Kuczaj (2001). The average lactose content $(4.89 \%)$ was growing with the increasing outside air temperature from $4.84 \%$ (in the group with outside air temperature below $1{ }^{\circ} \mathrm{C}$ ) to $4.94 \%$ (outside air temperatures above $15.1^{\circ} \mathrm{C}$ ). A similar trend was recorded by Polák et al. (2011) with average lactose content $4.80 \%$, the minimum $4.62 \%$ and the maximum $4.95 \%$. The casein content was almost constant, the changes were only minor (not significant).

Milk processing quality at the observed outside air temperature classes is described in Tab. III. The average titratable acidity was $6.31 \mathrm{SH}$ with the maximum of $6.39 \mathrm{SH}$ in the group with outside air temperature below $1{ }^{\circ} \mathrm{C}$ and the minimum of 6.26 $\mathrm{SH}$ at temperatures above $15.1^{\circ} \mathrm{C}$. Slightly higher values of titratable acidity were recorded

I: Milk temperature, volume and duration of transport within the observed outside air temperature range

\begin{tabular}{|c|c|c|c|c|c|c|}
\hline \multirow{3}{*}{ Characteristics } & \multirow{3}{*}{$\begin{array}{c}\text { Mean } \\
\mathrm{n}=\mathbf{2 0 8}\end{array}$} & \multirow{3}{*}{ Units } & \multicolumn{4}{|c|}{ Outside air temperature-based classes } \\
\hline & & & Below $1^{\circ} \mathrm{C}$ & 1.1 to $8^{\circ} \mathrm{C}$ & 8.1to $15^{\circ} \mathrm{C}$ & $\begin{array}{l}\text { Above } \\
15.1^{\circ} \mathrm{C}\end{array}$ \\
\hline & & & $\mathrm{n}=\mathbf{5 2}$ & $n=56$ & $\mathrm{n}=56$ & $n=44$ \\
\hline $\begin{array}{l}\text { Average outside air } \\
\text { temperature }\end{array}$ & 7.40 & {$\left[{ }^{\circ} \mathrm{C}\right]$} & $-3.48 \mathrm{~A}$ & 4.47B & $12.06 \mathrm{C}$ & 18.07D \\
\hline $\begin{array}{l}\text { Milk temperature-dairy } \\
\text { farms }\end{array}$ & 5.19 & {$\left[{ }^{\circ} \mathrm{C}\right]$} & $5.07 \mathrm{a}$ & $4.98 \mathrm{a}$ & $5.23 \mathrm{ab}$ & $5.57 b$ \\
\hline $\begin{array}{l}\text { Milk temperature-dairy } \\
\text { factory }\end{array}$ & 5.60 & {$\left[{ }^{\circ} \mathrm{C}\right]$} & $5.14 \mathrm{~A}$ & $5.38 \mathrm{AB}$ & $5.83 \mathrm{BC}$ & $6.14 \mathrm{C}$ \\
\hline $\begin{array}{l}\text { Temperature difference } \\
\text { between farm and factory }\end{array}$ & 0.41 & {$\left[{ }^{\circ} \mathrm{C}\right]$} & $0.07 \mathrm{~A}$ & $0.41 B$ & $0.60 \mathrm{~B}$ & $0.57 \mathrm{~B}$ \\
\hline Duration of transport & 211 & Minutes & 210 & 212 & 212 & 210 \\
\hline Milk volume in tanker & 12,885 & {$[\mathrm{~kg}]$} & 12,599 & 12,782 & 13,027 & 13,172 \\
\hline
\end{tabular}

Values in the same line marked with different symbols (a to d, or A to D, respectively) are different $(\mathrm{P}<0.05$ or $\mathrm{P}<0.01$, respectively)

II: Milk composition within the observed outside air temperature classes

\begin{tabular}{|c|c|c|c|c|c|c|}
\hline \multirow[b]{2}{*}{ Characteristic } & \multicolumn{6}{|c|}{ Air temperature-based classes } \\
\hline & $\begin{array}{c}\text { Mean } \\
n=208\end{array}$ & Unit & $\begin{array}{c}\text { Below } 1{ }^{\circ} \mathrm{C} \\
\mathbf{n}=52\end{array}$ & $\begin{array}{c}1 \text { to } 8^{\circ} \mathrm{C} \\
n=56\end{array}$ & $\begin{array}{c}8 \text { to } 15^{\circ} \mathrm{C} \\
n=56\end{array}$ & $\begin{array}{c}\text { Above } 15^{\circ} \mathrm{C} \\
n=44\end{array}$ \\
\hline Protein & 3.40 & $\%$ & $3.47 \mathrm{~A}$ & $3.47 \mathrm{~A}$ & $3.35 \mathrm{~B}$ & $3.28 \mathrm{C}$ \\
\hline Lactose & 4.89 & $\%$ & $4.84 \mathrm{~A}$ & $4.88 \mathrm{AB}$ & 4.90BC & $4.94 \mathrm{C}$ \\
\hline
\end{tabular}

Values in the same line marked with different symbols (a to d, or A to D, respectively) are different $(\mathrm{P}<0.05$ or $\mathrm{P}<0.01$, respectively). 
by Chládek et al. (2011) and Polák et al. (2011) - on average $7.16 \mathrm{SH}$, minimum $6.42 \mathrm{SH}$ and maximum 7.64 SH. The greatest difference (0.09 SH) was found between the groups with temperatures below $1{ }^{\circ} \mathrm{C}$ and 1.1 to $8{ }^{\circ} \mathrm{C}$. Falta et al. (2014) reported an almost identical difference (0.16 SH) which was insignificant in their study.

RCT was shortest in the group with temperatures above $15.1^{\circ} \mathrm{C}$ (194 s) and longest (209 s) in the group with temperatures between 1.1 and $8{ }^{\circ} \mathrm{C}$. Variability (16.25\%) was comparable to the values reported by Polák et al. (2011) or Čejna, (2008). The average RCT was 201s. Somewhat greater values were reported by FALTA et al.
(2014), and that was 244.3s during the season with the highest outside air temperatures.

Active acidity values remained constant throughout the observation (in average $6.75 \mathrm{pH}$ ).

Considering our previous experience with the visual evaluation of curd we extended the original 5-point system to a 10-point system in order to refine the evaluation and describe minute differences in curd quality. Although the quality of curd was best on both the 5-point and 10-points scale in classes with the highest temperatures (8.1 to $15^{\circ} \mathrm{C}$ and above $15.1^{\circ} \mathrm{C}$ ), findings suggest no significant interclass relationships at various intra-class scale differences.

III: Processing quality of milk within the observed outside air temperature classes range

\begin{tabular}{|c|c|c|c|c|c|c|}
\hline \multirow{3}{*}{ Property } & \multirow{3}{*}{$\begin{array}{c}\text { Mean } \\
\mathbf{n}=\mathbf{2 0 8}\end{array}$} & \multirow{3}{*}{ Unit } & \multicolumn{4}{|c|}{ Outside air temperature classes } \\
\hline & & & Below $1^{\circ} \mathrm{C}$ & 1 to $8^{\circ} \mathrm{C}$ & 8 to $15^{\circ} \mathrm{C}$ & Above $15^{\circ} \mathrm{C}$ \\
\hline & & & $\mathrm{n}=\mathbf{5 2}$ & $n=56$ & $n=56$ & $n=44$ \\
\hline Titratable acidity & 6.31 & $\mathrm{SH}$ & $6.39 \mathrm{~A}$ & $6.30 \mathrm{~B}$ & $6.27 \mathrm{~B}$ & $6.26 \mathrm{~B}$ \\
\hline Active acidity & 6.75 & $\mathrm{pH}$ & 6.75 & 6.75 & 6.76 & 6.75 \\
\hline RCT & 201 & Sec. & 202 & 209 & 199 & 194 \\
\hline Curd class (5) & 1.11 & 1 to 5 & 1.12 & 1.20 & 1.05 & 1.05 \\
\hline Curd class (10) & 1.49 & 1 to 10 & $1.52 \mathrm{AB}$ & 1.77B & $1.25 \mathrm{~A}$ & $1.41 \mathrm{~A}$ \\
\hline
\end{tabular}

Values in the same line marked with different symbols (a to d, or A to $\mathrm{D}$, respectively) are different $(\mathrm{P}<0.05$ or $\mathrm{P}<0.01$, respectively).

\section{CONCLUSIONS}

This study analysed the impact of outside air temperature during transport on the processing characteristics of milk and milk composition

In this study the analysis of data on 208 bulk samples of cow's milk suggest that the temperature of transported milk (on farm, at dairy and difference between them) increased with increasing outside air temperature.

In contrast the milk protein and fat content were decreasing with increasing outside air temperature. On the contrary, lactose content significantly increased and, the quality of curd and RCT was also better at higher temperatures. Our results further suggest that outside air temperature during transportation significantly influences the processing quality of the transported milk although the changes in the temperature of milk itself remains within the recommended limits $\left(4-6^{\circ} \mathrm{C}\right)$. It therefore stands to reason, that when the temperature of milk on load is close to the recommended temperature limit it can exceed this limit during transportation to the dairy factory.

\section{Acknowledgements}

This study was supported by research project FA MENDELU IGA TP 7/2017.

\section{REFERENCES}

BAYRAM, B., YANAR, M. and AKBULUT, O. 2009. The effect of average daily gain and age at first calving on reproductive and milk production traits of Brown Swiss and Holstein Friesian cattle. Bulg. J. Agric. Sci., 15(5): 453-462.

BITTANTE, G., PENESA, M. and CECCHINATO, A. 2012. Invited review genetics and modeling of milk coagulation quality, J Dairy Sci., 95(12): 6843-6870.

CASSANDRO, M., COMIN, A. and OJALA, M. 2008. Genetic parameters of milk coagulation quality and their relationships with milk yield and quality traits in Italian Holstein cows. J. Dairy Sci., 91(1): 371-376.

BONFATTI, V., ROSTELLATO, R. and CHIAROT, G. 2013. Effects of $\kappa$-CN Glycosylation on Rennet Coagulation Properties of Milk in Simmental Cattle. Mljekarstvo, 78(3): 163-166.

CIMEN, M., YILDIRIM, N. and DIKICI, A. 2010. Seasonal variations of biochemical taste parameters in milks from conventional and environment-friendly organic farming. Bulg. J. Agric. Sci., 16(6): 728-732.

COMIN, A., CASSANDRO, M. and POVINELLI, M. 2005. Genetic aspects of milk coagulation quality in Italian Holstein cows. Ital. J. Anim. Sci., 4(2): 10-12. 
ČEJNA, V. 2008. Zkušenosti z mlékárny se syřitelností mléka ve vazbě na dodavatele mléka. In: Výrobní zemédèlská praxe a potravinárské biotechnologické úpravy pro zvýraznèní pozitivních zdravotních vlivi mléka a mléčných výrobki̊. 8. 10.2008, Rapotín, VÚCHS, pp. 7-16.

ČEJNA, V., CHLÁDEK, G. and SKÝPALA, M. 2006. Vliv ročního období na obsah bílkovin v kravském mléce a výtěžnost sýrů. In: Proteiny 2006. Brno, MZLU, pp. 162-165.

DAVIAU, C., FAMELART, M. H. and PIERRE, A. 2000. Rennet coagulation of skim milk and curd drainage: Effect of $\mathrm{pH}$, casein concentration, ionic strength and heat treatment. Lait, 80(4): 397-415.

DAVIES, D. T. and WHITE, J. C. D. 1958. The relation between the chemical composition of milk and the stability of the caseinate complex. II. Coagulation by ethanol. J. Dairy Res, 25(2): 256-266.

GAJDU゚ŠEK, S. 1997. Mlékařství II: (cvičení). $1^{\text {st }}$ Edition. Brno: MZLU.

FALTA, D., ADAMSKI, M. and ČEJNA, V. 2014. The effect of outside air temperature and breed on bovine milk composition and its processing quality, Bulg. J. Agric. Sci., 20(1): 231-235.

HANUŠ, O., FRELICH, J. and JANU゚, L. 2007. Impact of different milk yields of cows on milk quality in Bohemian spotted cattle. Acta Vet. Brno. 76: 563-571.

HANUŠ, O., VYLETĚLOVÁ, M. and GENČUROVÁ, V. 2008. Hot stress of Holstein dairy cows as substantial factor of milk composition. Scientia Agriculturae Bohemica, 39(4): 310-317.

HANUŠ, O., FRELICH, J. and TOMĂŠKA, M. 2010. The analysis of relationships between chemical composition, physical, technological and health indicators and freezing point in raw cow milk. Czech J.Anim. Sci., 55(1): 11-29.

CHLÁDEK, G., ČEJNA, V. and FALTA, D. 2011. Effect of season and herd on rennet coagulation time and other parameters of milk technological quality in Holstein dairy cows, Acta univ. agric. et silvic. Mendel. Brun., 59(5): 113-118.

IKONEN, T., MORRI, S. and TYRISEVÄ, A. M. 2004. Genetic and phenotypic correlations between milk coagulation quality, milk production traits, somatic cell count, casein content, and pH of milk. J. Dairy Sci., 87(2): 458-467.

JAKOB, E. 1994. Genetic polymorphism of milk proteins. Bull. FIL/IDF, 298: 17-27.

JAKOB, E. and PUHAN, Z. 1992. Technological Quality of Milk as Influenced by Genetic Polymorphism of Milk Proteins. Int. Dairy J., 2(3): 157-178.

JANU゚, L., HANUŠ, O. and FRELICH, J. 2007. Influences of different milk yields of Holstein cows on milk quality indicators in the Czech Republic. Acta Vet. Brno, 76(4): 553-561.

JOHNSON, M. E., CHEN, C. M. and JAEGGI, J. J. 2001. Effect of rennet coagulation time on composition, yield and quality of reduced - fat cheddar cheese. J. Dairy Sci., 84(5): 1027-1033.

JỔUDU, I., HENNO, M. and KAART, T. 2008. The effect of milk proteins on the rennet coagulation quality of milk from individual dairy cows. Int. Dairy J., 18(9): 964-967.

KIRIN, S. 2001. The effect of cooling procedure on the characteristics and quality of raw milk. Mljekarstvo, 5l(2):251-159.

KUCZAJ, M. 2001. Interrelations between year season and raw milk hygienic quality indices, Electronic Journal of Polish Agricultural Universities, 4(1): \#01.

KÜBARSEPP, I., HENNO, M. and VIINALASS, H. 2005. Effect of $\kappa$-casein and $\beta$-lactoglobulin genotypes on the milk rennet coagulation quality. Agronomy Research, 3(1): 55-64.

LEGRAËT, Y. and BRULÉ, G. 1993. Effect of pH and ionic-strenght on distribution of mineral salts in milk. Lait: $73(1): 51-60$.

MATĚJÍČEK, A., MATĚJíČKOVÁ, J. and ŠTÍPKOVÁ, M. 2008. Joint effects of CSN3 and LGB genes on milk quality and coagulation quality in Czech Fleckvieh. Czech J. Anim. Sci., 53(6): 246-252.

MARZIALI, A. S. and NG-KWAI-HANG, K. F. 1986. Effects of milk composition and genetic polymorphism on coagulation quality of milk. J. Dairy Sci., 69(10): 2533-2542.

MASOERO, F., MOSCHINI, M. and FUSCONI, G. 2006. Raw, extruded and expanded pea (Pisum sativum) in dairy cows diet. Ital. J. Anim. Sci., 5(3): 237-247.

MARCHESINI, G., ANDRIGHETTO, I. and STEFANI, A. I. 2009. Effect of unsaturated fatty acid supplementation on performance and milk fatty acid profile in dairy cows fed a high fibre diet. Ital. J. Anim. Sci., 8(3): 391-403.

PAŠIĆ, V., TUDOR KALIT, M. and SALAJPAL, K. 2016. The impact of changes in the milk payment system and season on the hygienic quality of milk. Mljekarstvo, 17(3): 629-639.

POLÁK, O., FALTA, D. and HANUŠ, O. 2011. Effect of barn outside airspace temperature on composition and technological parameters of bulk milk produced by dairy cows of Czech Fleckvieh and Holstein breeds. Acta univ. agric. et silvic. Mendel. Brun., 59(6): 271-280.

RIDDELL-LAWRENCE, S. and HICKS, C. L. 1989. Effect of curd firmness on stirred curd cheese yield. J. Dairy Sci., 72(2): 313-321.

SUMMER, A., FORMAGGIONI, P. and MALACARNE, M. 2003. Composition, Acidity and Rennet-coagulation Quality of Early- and Late-lactation Milks from Italian Friesian Cows. Vet. Res. Commun., 27(1): 269-272.

TYRISEVÄ, A. M., VAHLSTEN, T. and RUOTTINEN, O. 2004. Non-coagulation of milk in Finnish Ayshire and Holstein-Friesian cows and effect of herds on milk coagulation ability. J. Dairy Sci., 87(11): 3958-3966. 
VARLYAKOV, I., PENEV, T. and MITEV, J. 2012. Effect of lameness on the behavior of dairy cows under intensive production systems. Bulg. J. Agric. Sci., 18(1): 125-132.

WEDHOLM, A., LARSEN, L. B. and LINDMARK-MANSSON, H. 2006. Effect of protein composition on the cheese-making quality of milk from individual dairy cows. J. Dairy Sci., 89(9): 3296-3305.

\section{Contact information}

Vratislav Henzl: xhenzl2@node.mendelu.cz 